\title{
The Isabel M. Priestly Plant Collection
} by George F. Ledingham, Regina

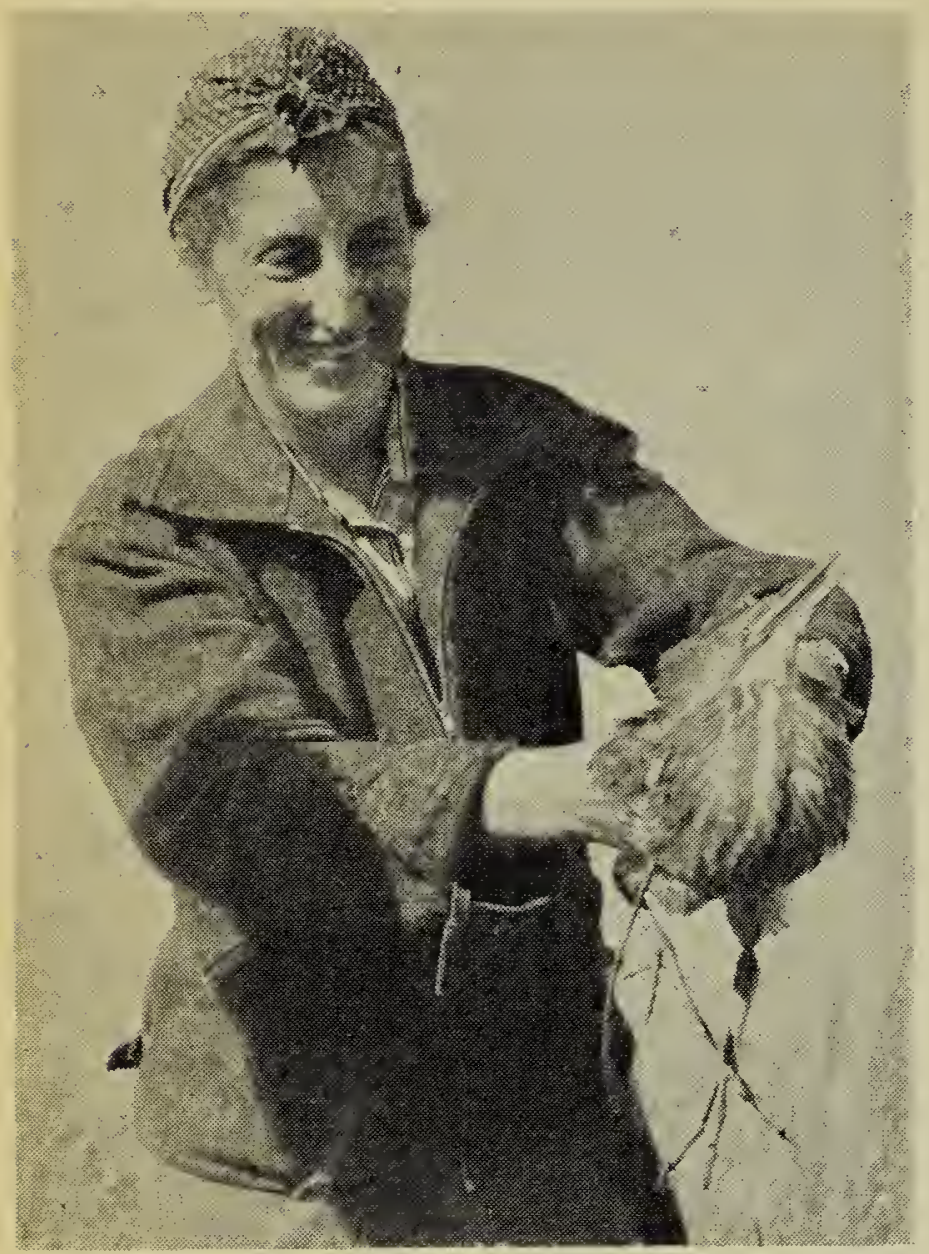

Mrs. Priestley with American Bittern.

Recently I had the pleasure of going through a collection of some 500 sheets of pressed and mounted plants. These plants had been donated to the Saskatchewan Museum of Natural History some time ago but they had not been sorted or filed with the specimens in the Museum herbarium. Having now filed these specimens for the Museum, it gives me considerable pleasure to acknowledge the gift in the Blue Jay and to express appreciation to the many people who must have helped with this collection.

Chief credit for the collection of 500 pressed plants must go to Mrs. Isabel M. Priestly. Mrs. Priestly was born in Newbury, Berkshire, England, on July 23, 1893. She studied botany in England, Germany, and Switzerland and her interest in plants continued until her death on April 23, 1946. She married in 1918 and after living in Winnipeg and Calgary she moved with her family, including two sons and one daughter, to Yorkton in 1935.

Most Blue Jay readers will know the name Isabel $M$. Priestly, for it appears on each copy of our magazine. Mrs. Priestly took the lead in organizing the Yorkton Natural History Society and with the help of a small group of young people she mimeographed the Blue Jay. The name of the newsletter was chosen by the young people because it was their aim to share their knowledge just as Sammy Jay in the Thornton Burgess stories told of things he saw. These young members of the Yorkton Natural History Society were an active group and getting out the Blue Jay was only one of their projects. Their energy and enthusiasm were responsible for the birth of the Saskatchewan Natural History Society which now has nearly 3,500 members.

The Isabel M. Priestly plant collection exists because Mrs. Priestly wanted to know the plants of the Yorkton area and because she knew how to collect, identify and care for a plant collection. Each specimen sheet has a neat label giving all the important data. The real purpose of this study collection was to develop the interests of the young members of the Yorkton Natural History Society and to teach them the food plants of ducks and other wildlife. The accompanying table shows the kind of work that Mrs. Priestly was doing in this regard.

Not only was the plant collection of value in teaching the plants of the area, but it also inspired other related activities. The drawing of the Shooting-star by Joy Nixon, which was with the collection, shows such another activity encouraged by Mrs. Priestly.

Mrs. Priestly's influence with the young members of the Yorkton Natural History Society has also been evident in other branches of

YORKTON NATURAL HISTORY SOCIETY

FAMILY Fabaceae
SPECIES Atelophragma alpinum
COMMON NAME Northern Atelophragma
LOCALITY Bredenbury
DATE JUIy 41945 COLLECTOR_I.M.Priestly


natural history. Stuart Houston continued the work begun by Mrs. Priestly in listing the birds of the Yorkton area, and published a check-list of the "Birds of the Yorkton District, Sask." (Can. Field-Nat., Vol. 63, No. 5, Sept-Oct. 1949). More recently he has been working on the "Birds of the Saskatchewan River" which will be Special Publication No. 2 of the' Saskatchewan Natural History Society. W. H. Beck developed his schoolboy enthusiasm for all wildlife, and has published "A Guide to Saskatchewan Mammals" (Special Publication No. 1, Saskatchewan Natural History Society, 1958). Both Houston and Beck were members of that original group of young people who formed the Yorkton Natural History Society and helped to put out the first Blue Jay.

It is unfortunate that Mrs. Priestly's death interrupted her serious study of the plants of Yorkton for her work was nearly complete. In her collection I was pleased to see about 40 species of Carex sedge collected by myself and sent to her before her death. She had been determined to learn even the most difficult species. I feel certain that given a few more years she would have completed her study and published a list of the plants of the Yorkton area. As it is, the Isabel M. Priestly plant collection is a valuable asset in the Saskatchewan Museum

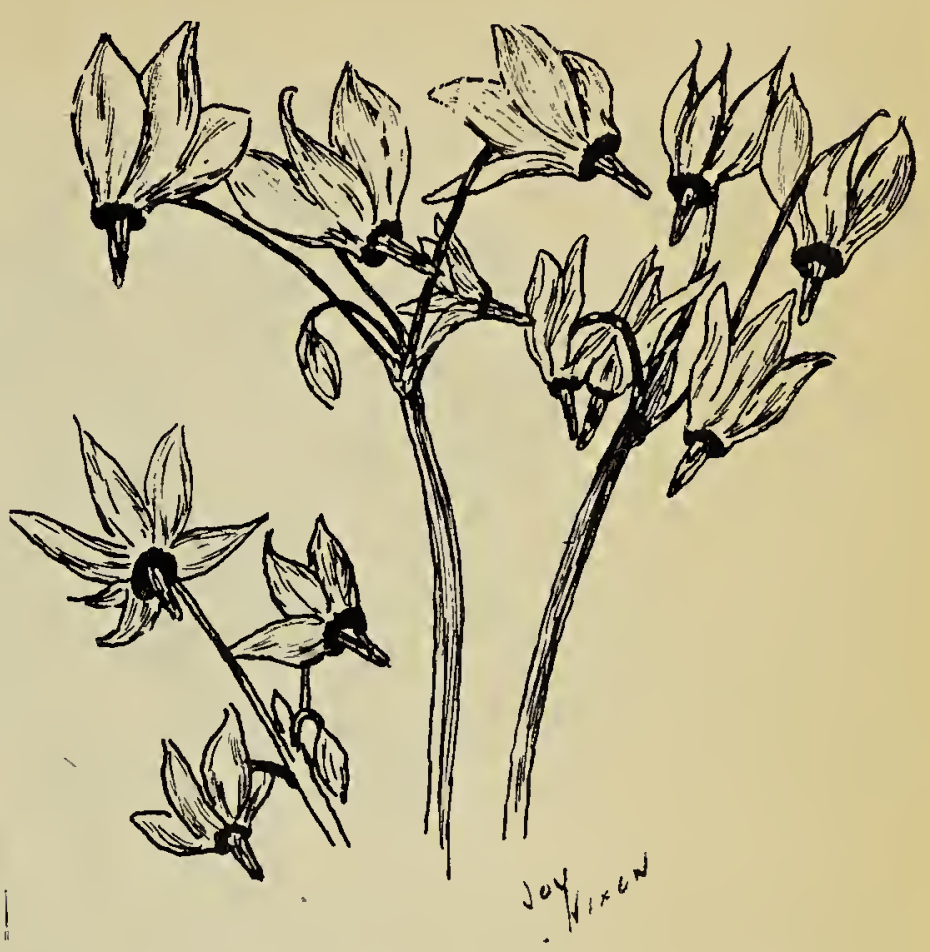

Sketch by Joy Nixon Shooting-star.

of Natural History where it gives real evidence of the wild plants growing in the Yorkton district. It is to be hoped that other individuals or clubs will make collections of the plants growing in their area and that these, too, will eventually be stored in the Saskatchewan Museum of Natural History.

\begin{tabular}{|c|c|c|c|}
\hline \multicolumn{4}{|c|}{ TABLE OF DUCK FOOD PLANTS AT ROUSAY LAKES } \\
\hline Scientific Name & Common Name & $\begin{array}{l}\text { Distribution at } \\
\text { Rousay Lakes }\end{array}$ & Parts Consumed \\
\hline Potamogeton* & Pondweed & Abundant & $\begin{array}{l}\text { Seeds, roots, } \\
\text { stems, leaves }\end{array}$ \\
\hline Scirpus & Bulrush & Abundant & Seeds \\
\hline Chara & Musk Grass & Not common & Whole plant \\
\hline Polygonum & Smartweed & Common & Seeds \\
\hline Myriophyllum & Water Milfoil & Abundant & $\begin{array}{l}\text { Seeds, plant as a } \\
\text { whole }\end{array}$ \\
\hline Carex & Sedge & Abundant & Seeds \\
\hline Sparganium & Bur-reed & Common & Seeds \\
\hline $\begin{array}{l}\text { Fluminia } \\
\text { festucacea }\end{array}$ & White-top & Abundant & Seeds \\
\hline Glyceria grandis & Manna Grass & Abundant & Seeds \\
\hline Eleocharis & Spike-rush & Abundant & Seeds, roots \\
\hline Sagittaria & Arrowhead & Not common & Seeds, roots \\
\hline Lemna & Duckweed & Common & Whole plant \\
\hline Ranunculus & Buttercup & Common & Seeds, roots, leaves \\
\hline Hippuris & Mare's Tail & Common & $\begin{array}{l}\text { Seeds, plant as a } \\
\text { whole }\end{array}$ \\
\hline Symphoricarpos & Snowberry & Common & Berries \\
\hline Rosa & Wild Rose & Common & Berries \\
\hline
\end{tabular}

